\title{
PENGARUH BUDAYA ORGANISASI DAN MOTIVASI KERJA TERHADAP KEPUASAN KERJA SERTA IMPLIKASINYA TERHADAP KINERJA KARYAWAN
}

\author{
Irwan Sugiarto* \\ Sekolah Tinggi Hukum Bandung
}

\begin{abstract}
The study is titled "The Effect of Organizational Culture and Work Motivation And On The Job Satisfaction on Employee Performance Implications".

Research objectives are: 1) to determine and assess the organizational culture, employee motivation, job satisfaction and employee performance, 2) to determine the influence of organizational culture and work motivation partially on employee job satisfaction, and 3) to determine the influence of organizational culture and motivation simultaneously work on employee job satisfaction; 4) to determine the influence of job satisfaction on employee performance.

The research was conducted by PT Industri Telekomunikasi Indonesia (Persero), by taking a sample of 190 employees from a population of 625 employees. The method used is descriptive method using path analysis (path analysis), and operate calculation using PASW Statistics 18 software.

Results of this study are as follows: 1) organizational culture significantly influence employee job satisfaction, with the magnitude of the effect of $36.5 \%, 2)$ work motivation significantly influence employee job satisfaction, with the magnitude of the effect of 39.8\%; 3 ) organizational culture and work motivation simultaneously significant effect on employee job satisfaction, with the magnitude of the effect of $76.4 \%$; 4) job satisfaction have a significant effect on the performance of employees, with the magnitude of the effect of $81.1 \%$.

The conclusion of this research is proven there is significant relationship between organizational culture and work motivation on job satisfaction as well as implications for the performance of employees at PT Industri Telekomunikasi Indonesia (Persero).
\end{abstract}

Keywords : organizational culture, employee motivation, job satisfaction, employee performance, PT. INTI, PT Industri Telekomunikasi Indonesia (Persero).

\section{Pendahuluan}

Perkembangan ekonomi dunia berlangsung sangat dinamis, terutama berkaitan dengan liberalisasi dan globalisasi perdagangan yang telah disepakati oleh dunia internasional seperti kesepakatan mengenai World Trade Organization (WTO), ASEAN Free Trade Area (AFTA), ASEAN Framework Agreement on Service, dan kerjasama ekonomi regional Asia Pacific (Asia Pacific Economic Cooperation/APEC).

Tantangan global yang dihadapi dunia saat ini tidak dapat dihindari baik dari sektor pemerintah maupun swasta, mau tidak mau semua pihak dituntut untuk mempersiapkan diri sehingga dapat bertahan dalam menghadapi kondisi tersebut. Manajemen perusahaan harus menentukan tujuan dan sasaran perusahaan secara jelas, agar strategi yang dipilih dan ditetapkan dapat berfungsi secara efektif dalam pencapaian tujuan dan sasaran perusahaan, sehingga mampu bersaing dalam pasar global.

Persaingan dalam pasar global dapat dimenangkan jika perusahaan selalu menyediakan pelayanan yang superior bagi konsumen, mengembangkan kapabilitas baru dan komitmen pada kualitas, mengembangkan inovasi, kreatifitas, insiatif dan mengelola sumber daya manusia secara efektif (Walker, 1992:1 dalam Praningrum, 2002:158).

Demikian pula halnya dengan para pelaku kegiatan ekonomi di Indonesia harus siap memasuki gelombang globalisasi. Konstitusi Undang-Undang Dasar (UUD) 1945 mengamanatkan bahwa pelaku utama dalam sistem perekonomian Indonesia adalah: Badan Usaha Milik Negara (BUMN); Badan Usaha Milik Swasta (BUMS); dan Koperasi. Dalam

\footnotetext{
* Dosen Tetap Sekolah Tinggi Hukum Bandung, Pengajar Mata Kuliah Dasar-Dasar Manajemen dan Ekonomi Makro
} 
menjalankan kegiatan usahanya, BUMN, swasta dan koperasi melaksanakan peran saling mendukung berdasarkan demokrasi ekonomi.

Dalam sistem perekonomian nasional, BUMN ikut berperan menghasilkan barang dan/atau jasa yang diperlukan dalam rangka mewujudkan sebesar-besarnya kemakmuran masyarakat. Peran BUMN dirasakan semakin penting sebagai pelopor dan/atau perintis dalam sektor-sektor usaha yang belum diminati usaha swasta. Di samping itu, BUMN juga mempunyai peran strategis sebagai pelaksana pelayanan publik, penyeimbang kekuatan-kekuatan swasta besar, dan turut membantu pengembangan usaha kecil/koperasi. BUMN juga merupakan salah satu sumber penerimaan negara yang signifikan dalam bentuk berbagai jenis pajak, dividen dan hasil privatisasi.

Dalam kenyataannya, walaupun BUMN telah mencapai tujuan awal sebagai agen pembangunan dan pendorong terciptanya korporasi, namun tujuan tersebut dicapai dengan biaya yang relatif tinggi. Kinerja perusahaan dinilai belum memadai, seperti tampak pada rendahnya laba yang diperoleh dibandingkan dengan modal yang ditanamkan. Dikarenakan berbagai kendala, BUMN belum sepenuhnya dapat menyediakan barang dan/atau jasa yang bermutu tinggi bagi masyarakat dengan harga yang terjangkau serta belum mampu berkompetisi dalam persaingan bisnis secara global. Selain itu, karena keterbatasan sumber daya, fungsi BUMN baik sebagai pelopor/perintis maupun sebagai penyeimbang kekuatan swasta besar, juga belum sepenuhnya dapat dilaksanakan (Penjelasan UU No.19 Tahun 2003 Tentang BUMN).

Di era kompetisi bisnis yang ketat seperti sekarang ini, hubungan baik yang terjalin antara perusahaan dan pelanggannya adalah suatu hal yang mutlak. Itu pula yang mendasari PT Industri Telekomunikasi Indonesia (Persero), yang lebih dikenal dengan sebutan PT. INTI (Persero), untuk menggunakan Trusted Partner sebagai motto perusahaan. PT INTI (Persero) berusaha untuk menjadi mitra terpercaya bagi customer-nya dengan memberikan dukungan semaksimal mungkin.

PT INTI (Persero) merupakan salah satu perusahaan BUMN yang telah berkecimpung selama 35 tahun lebih di bidang industri telekomunikasi. Pada tahun 2008, banyak perusahaan yang diterpa krisis finansial global, begitu juga dengan yang dialami oleh PT. INTI (Persero) hingga mengalami kerugian sebesar Rp.15,32 miliar. Permasalahan yang dialami oleh PT INTI (Persero) beberapa tahun terakhir ini adalah penurunan kinerja perusahaan, hal ini dapat dilihat dari turunnya laba bersih yang diperoleh perusahaan dari tahun ke tahun, sebagaimana dikemukakan oleh Irfan Setiaputra, CEO PT INTI (Persero) dalam wawancara dengan Hendro Adiarso dan Eko Napitupulu (FMPM Vol XXIV No. 04, Juli-September 2010) yang menyatakan:

“...tahun 2008 harus menelan pil pahit karena rugi Rp 15,32 miliar. Sementara tahun 2007 tidak minus, tetapi untungnya lebih kecil, yakni Rp 1,38 miliar. Padahal, tahun 2006 pernah mendulang masa kejayaan dengan laba bersih Rp 8,63 miliar...”.

Keberhasilan suatu organisasi/perusahaan dipengaruhi oleh kinerja (job performance) karyawan, untuk itu setiap perusahaan akan berusaha untuk meningkatkan kinerja karyawannya dalam mencapai tujuan organisasi yang telah ditetapkan. Gibson (1996) dalam Ermayanti (2001:3) dan Brahmasari (2005:96), mengemukakan bahwa kinerja organisasi tergantung dari kinerja individu atau dengan kata lain kinerja individu akan memberikan kontribusi pada kinerja organisasi, artinya bahwa perilaku anggota organisasi baik secara individu maupun kelompok memberikan kekuatan atas kinerja organisasi sebab motivasinya akan mempengaruhi pada kinerja organisasi.

Setiap perusahaan akan selalu berusaha untuk meningkatkan kinerja karyawan dengan harapan apa yang menjadi tujuan perusahaan akan tercapai. Berbagai cara akan ditempuh oleh perusahaan dalam meningkatkan kinerja karyawannya, misalnya dengan memperhatikan kepuasan kerja karyawan dan memberikan motivasi kepada karyawan tersebut.

Membahas kepuasan kerja tidak akan terlepas dengan adanya faktor-faktor yang dapat mempengaruhi kepuasan kerja seseorang. Persoalan kepuasan kerja akan dapat terlaksana dan terpenuhi apabila beberapa variabel yang mempengaruhinya mendukung sekali. Variabel yang dimaksud adalah Culture dan Motivation. Dapat dikatakan pula bahwa secara tidak langsung 
ketiga variabel tersebut mempengaruhi kinerja seseorang dan pada ujung-ujungnya kinerja perusahaan dapat tercapai dengan baik. Sehubungan dengan hal tersebut, agar karyawan selalu konsisten dengan kepuasannya, maka setidak-tidaknya perusahaan selalu memperhatikan lingkungan di mana karyawan melaksanakan tugasnya misalnya rekan kerja, pimpinan, suasana kerja dan hal-hal lain yang dapat mempengaruhi kemampuan seseorang dalam menjalankan tugasnya (Koesmono, 2005:163-164).

Irfan Setiaputra, CEO PT INTI (Persero) dalam wawancara dengan Hendro Adiarso dan Eko Napitupulu (FMPM Vol XXIV No. 04, Juli-September 2010) menyatakan bahwa:

“...Saya dan direksi yang baru dilantik Maret 2009 lalu mewarisi sebuah perusahaan yang sedang carut marut. Representasi dari situasi itu adalah laporan keuangan, yang waktu itu minus. Apa yang saya lakukan?... Bagi saya dan manajemen, yang terpenting dalam organisasi perusahaan adalah SDM. Justru akan menjadi masalah besar bila 700 karyawan tidak termotivasi untuk melakukan upaya-upaya drastis di perusahaan tempat kita bekerja. Berangkat dari pola pikir itu, akhirnya kami membuat keputusan berani. Ketika kondisi keuangan perusahaan minus, kita justru berani menaikkan gaji karyawan sampai 43\%. Cara ini dilakukan guna mendongkrak motivasi karyawan agar lebih baik lagi. Kebetulan, gaji karyawan kala itu masih di bawah rata-rata industri. Memang, meningkatkan motivasi itu bisa dengan berbagai cara, baik ancaman atau menaikkan gaji. Dan kami pilih untuk menaikkan gaji... Mereka senang direksi memprioritaskan kesejahteraan karyawan untuk kemudian membangun kemajuan perusahaan".

Setelah motivasi karyawan dibenahi, kemudian direksi menata organisasi perusahaan. PT. INTI (Persero) sebagai salah satu Badan Usaha Milik Negara, wajib menerapkan tata kelola perusahaan yang baik (Good Corporate Governance/GCG), hal ini sesuai dengan Pasal 2 ayat (1) Keputusan Menteri Badan Usaha Milik Negara Nomor: KEP-117/M-MBU/2002 Tentang Penerapan Praktek Good Corporate Governance Pada Badan Usaha Milik Negara (BUMN) yang menyatakan bahwa BUMN wajib menerapkan good corporate governance secara konsisten dan atau menjadikan good corporate governance sebagai landasan operasionalnya.

Good Corporate Governance (Tata Kelola Perusahaan yang Baik) merupakan prinsipprinsip yang mengarahkan dan mengendalikan perusahaan agar mencapai keseimbangan antara kekuatan serta kewenangan perusahaan dalam memberikan pertanggung-jawabannya kepada stakeholders. Prinsip-prinsip tersebut dijadikan sebagai perangkat standar yang bertujuan untuk memperbaiki citra, efisiensi, efektifitas dan tanggung-jawab sosial perusahaan. Prinsip-prinsip GCG adalah transparansi, akuntabilitas, responsibilitas, independensi dan fairness.

Sebagai salah satu implementasi penerapan GCG di lingkungan PT. INTI (Persero), salah satunya pada bulan Oktober 2009, PT. INTI (Persero) meluncurkan Budaya "Harmony". Adapun maksud dan tujuan diluncurkannya Budaya "Harmony": diantaranya menanamkan nilai-nilai yang sama pada setiap karyawannya, menciptakan rasa kesatuan dan kebanggaan masing-masing karyawan; sehingga pada akhirnya mereka mampu mengakomodasi perubahan ke dalam perusahaan menuju arah yang positif.

Budaya perusahaan memiliki peranan penting dalam membangun prestasi dan produkivitas kerja para karyawan. Budaya organisasi membentuk perilaku karyawan dan mendorong percampuran core values (nilai-nilai dominan) dan perilaku yang diinginkan sehingga memungkinkan organisasi bekerja dengan lebih efisien dan efektif, meningkatkan konsisten, menyelesaikan konflik dan memfasilitasi koordinasi dan kontrol. Budaya organisasi akan meningkatkan motivasi kerja karyawan dengan memberi mereka perasaan memiliki, loyalitas, kepercayaan dan nilai-nilai dan mendorong mereka berpikir positif tentang mereka dan organisasi. Dengan demikian, organisasi itu memaksimalkan potensi karyawan dan memenangkan kompetisi. Budaya organisasi juga akhirnya akan berfungsi sebagai motivator bagi karyawan dalam melaksanakan pekerjaannya.

Kinerja karyawan merupakan faktor penting yang perlu diperhatikan oleh setiap perusahaan, karena kinerja karyawan akan mempengaruhi kualitas dan kuantitas perusahaan dalam menghadapi persaingan seiring dengan perkembangan kompetisi bisnis. 
Berdasarkan uraian di atas, maka dipandang perlu untuk melakukan penelitian mengenai pengaruh budaya organisasi dan motivasi kerja terhadap kepuasan kerja serta implikasinya terhadap kinerja karyawan.

\section{Kajian Literatur \\ Budaya Organisasi}

Dalam Beberapa literatur sering dijumpai penggunaan terminologi budaya dan budaya organisasi, ada yang secara tegas membedakan kata budaya dan budaya organisasi, namun ada pula yang menggunakan kata budaya, tetapi dalam pembahasan selanjutnya tampak bahwa yang dimaksudkan adalah budaya organisasi.

Schein (dalam Muchlas, 2005:531) mendefinisikan budaya organisasi sebagai sebuah corak dan asumsi-asumsi dasar-ditemukan atau dikembangkan oleh sebuah kelompok tertentu untuk belajar mengatasi problem-problem kelompok dari adaptasi eksternal dan integrasi internal-yang telah bekerja dengan baik, cukup relevan untuk dipertimbangkan sebagai sesuatu yang benar untuk berpersepsi, berpikir dan berperasaan dalam hubungannya dengan problemproblem tersebut.

Adapun menurut Kreitner dan Kinicki (dalam Wibowo, 2010:17), budaya organisasi adalah nilai-nilai dan keyakinan bersama yang mendasari identitas perusahaan. Definisi Kreitner dan Kinicki ini menunjukkan tiga karakteristik penting budaya organisasi, yaitu : (1) budaya organisasi diteruskan kepada pekerja baru melalui proses sosialisasi, (2) budaya organisasi mempengaruhi perilaku di pekerjaan, dan (3) budaya organisasi bekerja pada dua tingkatan yang berbeda.

PT. INTI (Persero) sebagai salah satu Badan Usaha Milik Negara, menerapkan implementasi GCG di lingkungan PT. INTI (Persero), salah satunya pada bulan Oktober 2009, PT. INTI (Persero) meluncurkan Budaya "Harmony", yaitu nilai-nilai budaya perusahaan membentuk perilaku seluruh insan INTI dalam melaksanakan hubungan dengan pemegang saham, pemerintah, customer, supplier, kreditor, mitra kerja lain, pesaing dan masyarakat di mana Perusahaan beroperasi. Setiap insan INTI diwajibkan menerapkan nilai-nilai budaya Perusahaan dalam melaksanakan pekerjaannya.

Nilai-nilai budaya Perusahaan PT. INTI (Persero) adalah Integrity, Network, Trust, teamwork, Innovative:

- Integritas/lntegrity adalah tetap bertindak jujur terhadap apa yang kita yakini. Setia terhadap kejujuran, keadilan, dan melakukan hal yang benar, walaupun dalam kondisi yang sulit dan tidak populer.

- Network adalah membangun, memelihara dan memanfaatkan jaringan kerja yang luas dan mendayagunakan kontak bisnis yang luas demi kepentingan Perusahaan.

- Trust adalah kemampuan untuk mempercayai orang lain termasuk kepercayaan pada prosedur dan aturan main.

- team-work atau kerjasama adalah bekerja dengan kooperatif dan menempatkan diri dan kelompok secara sinergi sebagai bagian Perusahaan.

- Inovatif atau innovative adalah menemukan atau menciptakan ide, pemikiran dan cara baru yang lebih baik dari sebelumnya.

Budaya organisasi adalah filosofi dasar organisasi yang memuat keyakinan, normanorma, dan nilai-nilai bersama yang menjadi karakteristik inti tentang bagaimana cara melakukan sesuatu dalam organisasi. Keyakinan, norma-norma, dan nilai-nilai tersebut menjadi pegangan semua sumber daya manusia dalam organisasi melaksanakan kinerjanya.

\section{Motivasi Kerja}

Motivasi dalam manajemen ditunjukan pada sumber daya manusia umumnya dan bawahan khususnya. Motivasi mempersoalkan bagaimana cara mengarahkan daya dan potensi bawahan, agar mau bekerja sama secara produktif berhasil mencapai dan mewujudkan tujuan yang telah ditentukan. Pentingnya motivasi karena menyebabkan, menyalurkan, dan 
mendukung perilaku manusia, supaya mau bekerja giat dan antusias mencapai hasil yang optimal.

Manfaat motivasi yang utama adalah menciptakan gairah kerja, sehingga produktivitas kerja meningkat. Sementara itu, manfaat yang diperoleh karena bekerja dengan orang-orang yang termotivasi adalah pekerjaan dapat diselesaikan dengan tepat. Artinya pekerjaan diselesaikan sesuai standar yang benar dan dalam skala waktu yang sudah ditentukan, serta orang senang melakukan pekerjaannya. Sesuatu yang dikerjakan karena ada motivasi yang mendorongnya akan membuat orang senang mengerjakannya. Orang pun akan merasa dihargai/diakui, hal ini terjadi karena pekerjaannya itu betul-betul berharga bagi orang yang termotivasi, sehingga orang tersebut akan bekerja keras. Hal ini dimaklumi, karena dorongan yang begitu tinggi menghasilkan sesuai target yang mereka tetapkan. Kinerjanya akan dipantau oleh individu yang bersangkutan dan tidak akan membutuhkan terlalu banyak pengawasan serta semangat juangnya akan tinggi.

Memberikan motivasi kepada karyawan oleh pimpinannya merupakan proses kegiatan pemberian motivasi kerja, sehingga pegawai tersebut berkemampuan untuk pelaksanaan pekerjaan dengan penuh tanggung jawab. Tanggung jawab adalah kewajiban bawahan untuk melaksanakan tugas sebaik mungkin yang diberikan oleh atasan, dan inti dari tanggung jawab adalah kewajiban.

Orang-orang yang termotivasi akan melakukan pekerjaannya lebih baik daripada yang tidak. Namun, pernyataan ini bersifat relatif. Faktor-faktor yang mempengaruhi motivasi anggota organisasi berbeda satu dengan yang lainnya, termasuk dalam hal kebutuhan dan keinginan. Hal ini berbeda karena setiap anggota organisasi adalah unik secara biologis maupun psikologis, dan berkembang atas dasar proses yang berbeda pula. Motivasi dapat ditafsirkan dan diartikan berbeda oleh setiap orang sesuai tempat dan keadaan dari para masing-masing orang itu. Pandangan para penulis tentang motivasi sangat bervariasi menurut sudut pandang masingmasing.

Motivasi kerja adalah dorongan yang muncul pada diri individu untuk secara sadar melakukan pekerjaan yang dihadapi (Danim, 2004:23). Motivasi kerja merupakan sesuatu yang menimbulkan semangat atau dorongan kerja. Kuat dan lemahnya motivasi kerja karyawan sangat menentukan tinggi atau rendahnya prestasi kerja yang dicapainya.

Rivai dan Sagala (2010:837) mengatakan bahwa motivasi kerja adalah serangkaian sikap dan nilai-nilai yang mempengaruhi individu untuk mencapai hal yang spesifik sesuai dengan tujuan individu. Sikap dan nilai tersebut merupakan suatu yang invisible yang memberikan kekuatan untuk mendorong individu bertingkah laku dalam mencapai tujuan. Dorongan tersebut terdiri dari dua komponen, yaitu: arah perilaku (kerja untuk mencapai tujuan), dan kekuatan perilaku (seberapa kuat usaha individu dalam bekerja). Motivasi meliputi perasaan unik, pikiran dan pengalaman masa lalu yang merupakan bagian dari hubungan internal dan eksternal perusahaan. Selain itu motivasi dapat pula diartikan sebagai dorongan individu untuk melakukan tindakan karena mereka ingin melakukannya.

Robbins dan Judge (2008:222-223) mendefinisikan motivasi (motivation) sebagai proses yang menjelaskan intensitas, arah, dan ketekunan seorang individu untuk mencapai tujuannya. Tiga elemen utama dalam definisi ini adalah intensitas, arah, dan ketekunan. Intensitas berhubungan dengan seberapa giat seseorang berusaha. Ini adalah elemen yang paling banyak mendapat perhatian ketika membicarakan tentang motivasi. Namun, intensitas yang tinggi tidak akan menghasilkan prestasi kerja yang memuaskan kecuali upaya tersebut dikaitkan dengan arah yang menguntungkan organisasi. Dengan demikian, harus dipertimbangkan kualitas serta intensitas upaya secara bersamaan. Upaya yang diarahkan ke, dan konsisten dengan, tujuan-tujuan organisasi merupakan jenis upaya yang seharusnya dilakukan. Elemen terakhir, motivasi memiliki dimensi ketekunan. Dimensi ini merupakan ukuran mengenai berapa lama seseorang bisa mempertahankan usahanya. Individu-individu yang termotivasi bertahan melakukan suatu tugas dalam waktu yang cukup lama demi mencapai tujuan mereka.

Herzberg (dalam Robbins dan Judge, 2008:227) memperkenalkan teori dua faktor (two factor theory) yang disebut teori motivasi higiene (motivation hygiene theory), yang 
berkeyakinan bahwa hubungan seorang individu dengan pekerjaannya merupakan hubungan dasar dan bahwa sikap seseorang terhadap pekerjaan bisa dengan sangat baik menentukan keberhasilan atau kegagalan. Lebih lanjut Herzberg (dalam Robbins dan Judge, 2008:227) menyatakan bahwa terdapat faktor yang diinginkan seseorang terhadap pekerjaan mereka. Dari respon yang dikategorikan, diketahui bahwa respon mereka yang merasa senang berbeda dengan respon mereka yang tidak merasa senang. Beberapa faktor tertentu cenderung secara konsisten terkait dengan kepuasan kerja. Faktor intrinsik seperti kemajuan, pengakuan, dan tanggung jawab terkait dengan kepuasan kerja. Responden yang merasa senang dengan pekerjaan mereka cenderung mengkaitkan faktor ini dengan diri mereka.

Di pihak lain, bila mereka tidak puas, mereka cenderung mengkaitkan dengan faktorfaktor ekstrinsik seperti: pengawasan, gaji, kebijakan perusahaan, dan kondisi pekerjaan. Lebih lanjut menurut Herzberg (dalam Robbins dan Judge, 2008:228), faktor-faktor yang menyebabkan kepuasan kerja terpisah dan berbeda dari faktor-faktor yang menimbulkan ketidakpuasan kerja. Oleh karena itu, manajer yang berusaha menghilangkan faktor-faktor yang menciptakan ketidakpuasan kerja dapat membawa ketenteraman tetapi belum tentu memotivasi. Mereka akan menenteramkan tenaga kerja, bukannya memotivasi mereka. Akibatnya, kondisikondisi yang melingkupi pekerjaan seperti kualitas pengawasan, gaji, kebijakan perusahaan, hubungan antarpribadi, kondisi kerja fisik, dan keamanan kerja telah dicirikan oleh Herzberg sebagai faktor-faktor higiene. Jika ingin memotivasi orang pada pekerjaannya, Herzberg menyarankan untuk menekankan pada hal-hal yang berhubungan dengan kerja itu sendiri atau hasil langsung yang diakibatkannya, seperti: peluang promosi, peluang pertumbuhan personal, pengakuan, tanggung jawab dan prestasi. Inilah karakteristik yang dianggap sebagai hal yang menguntungkan secara intrinsik.

Pemberian motivasi sangat penting karena pemimpin atau manajer memerlukan kerjasama yang baik dengan bawahannya untuk melaksanakan tugas-tugas organisasi dalam mencapai tujuan yang ditetapkan. Pentingnya pemberian motivasi kepada bawahan yaitu agar mereka tetap mau dan bersedia melaksanakan tugas-tugasnya sesuai dengan keahlian atau keterampilan yang mereka miliki.

\section{Kepuasan Kerja}

Kepuasan kerja sebenarnya mempunyai makna bagi seorang pekerja, ada dua kata yaitu kepuasan dan kerja. Kepuasan adalah sesuatu perasaan yang dialami oleh seseorang, di mana yang diharapkan telah terpenuhi atau bahkan yang diterima melebihi yang diharapkan, sedangkan kerja merupakan usaha seseorang untuk mencapai tujuan dengan memperoleh pendapatan atau kompensasi dari kontribusinya kepada pekerjaannya.

Greenberg dan Baron (dalam Wibowo, 2011:501) mendeskripsikan kepuasan kerja sebagai sikap positif atau negatif yang dilakukan individu terhadap pekerjaan mereka. Selain itu Gibson (dalam Wibowo, 2011:501) menyatakan kepuasan kerja sebagai sikap yang dimiliki para pekerja tentang pekerjaan mereka. Hal itu merupakan hasil dari persepsi mereka tentang pekerjaan.

Robbins dan Judge (2008:99) menyatakan bahwa kepuasan kerja (job satisfaction) sebagai suatu perasaan positif tentang pekerjaan seseorang yang merupakan hasil dari sebuah evaluasi karakteristiknya. Seseorang dengan tingkat kepuasan kerja yang tinggi memiliki perasaan-perasaan positif tentang pekerjaan tersebut, sementara orang yang tidak puas memiliki perasaan-perasaan yang negatif tentang pekerjaan.

Luthans (2006:243), menyatakan bahwa terdapat tiga dimensi penting dari kepuasan kerja. Pertama, kepuasan kerja merupakan respon emosional terhadap situasi dan kondisi kerja. Kedua, kepuasan kerja seringkali menentukan seberapa besar hasil yang akan dicapai atau harapan-harapan yang akan dilampaui. Misalnya, bila anggota organisasi merasa bahwa mereka bekerja lebih keras daripada yang lainnya dalam suatu departemen tetapi menerima imbalan lebih sedikit, maka mereka akan memiliki sikap negatif terhadap pekerjaan, pimpinan dan rekan sekerjanya. Mereka akan menjadi tidak puas. Sebaliknya jika mereka merasa diperlakukan dengan baik dan dibayar dengan adil, maka mereka akan memiliki sikap yang positif terhadap 
pekerjaannya. Ketiga, kepuasan kerja mencerminkan sikap yang berhubungan dengan pekerjaan itu sendiri.

Selama bertahun-tahun, lima dimensi pekerjaan telah diidentifikasi untuk merepresentasikan karakteristik pekerjaan yang paling penting di mana karyawan memiliki respon afektif. Kelima dimensi tersebut adalah sebagai berikut:

1) Pembayaran, seperti gaji dan upah.

Karyawan menginginkan sistem upah yang dipersepsikan sebagai adil, tidak merugikan dan segaris dengan pengharapannya. Bila upah dilihat sebagai adil yang didasarkan pada tuntutan pekerjaan, tingkat keterampilan individu dan standar pengupahan komunitas kemungkinan besar akan dihasilkan kepuasan. Pembayaran gaji dan upah besarnya berprinsipkan pada keadilan, dan obyektifitas dari kinerja, tugas dan tanggung jawab para karyawan.

2) Pekerjaan itu sendiri.

Karyawan cenderung lebih menyukai pekerjaan-pekerjaan yang memberi kesempatan untuk menggunakan kemampuan dan keterampilannya, kebebasan dan umpan balik mengenai betapa baik mereka bekerja. Karakteristik ini membuat kerja lebih menantang. Pekerjaan yang kurang menantang menciptakan kebosanan, tetapi yang terlalu banyak menantang juga dapat menciptakan frustasi dan perasaan gagal.

3) Rekan kerja.

Bagi kebanyakan karyawan, kerja juga mengisi kebutuhan akan interaksi sosial. Oleh karena itu tidaklah mengejutkan bila mempunyai rekan kerja yang ramah dan mendukung menghantar ke kepuasan kerja yang meningkat. Sejauh mana terciptanya lingkungan kerja yang baik diantara para karyawan dan lingkungan kerja yang ada, sehingga tercipta interaksi sosial yang baik diantara para karyawan yang mendorong peningkatan produktivitas dan motivasi dalam bekerja.

4) Promosi pekerjaan.

Promosi terjadi pada saat seorang karyawan berpindah dari suatu pekerjaan ke posisi lainnya yang lebih tinggi, dengan tanggung jawab dan jenjang organisasionalnya. Pada saat dipromosikan karyawan umumnya menghadapi peningkatan tuntutan dan keahlian, kemampuan dan tanggung jawab. Sebagian besar karyawan merasa positif karena dipromosikan. Promosi memungkinkan perusahaan untuk mendayagunakan kemampuan dan keahlian karyawan setinggi mungkin.

5) Kepenyeliaan (supervise).

Supervisi mempunyai peran yang penting dalam manajemen. Supervisi berhubungan dengan karyawan secara langsung dan mempengaruhi karyawan dalam melakukan pekerjaannya. Umumnya karyawan lebih suka mempunyai supervise yang adil, terbuka dan mau bekerjasama dengan bawahan. Sejauh mana para atasan memiliki sifat kepemimpinan yang baik yang bisa membangun dan memotivasi pada anggotanya dengan baik.

\section{Kinerja Karyawan}

Menurut Oxford Dictionary, kinerja (performance) merupakan suatu tindakan, proses dan atau cara bertindak atau melakukan fungsi. Kinerja merupakan suatu konstruk, di mana banyak para ahli yang masih memiliki sudut pandang yang berbeda dalam mendefinisikan kinerja (Moeheriono, 2009:61).

Rivai et.al. (2008:16) menyatakan bahwa kinerja tidak berdiri sendiri tapi berhubungan dengan kepuasan kerja dan kompensasi, sehingga dengan kata lain kinerja ditentukan oleh kemampuan, keinginan dan lingkungan. Oleh karena itu agar mempunyai kinerja yang baik, seseorang harus mempunyai keinginan tinggi untuk mengerjakan dan mengetahui pekerjaannya serta dapat ditingkatkan apabila ada kesesuaian antara pekerjaan dan kemampuan.

Bagi individu, organisasi adalah wadah untuk mencapai tujuan-tujuan yang tidak dapat direalisasikan secara individual, baik tujuan pribadi maupun tujuan organisasi. Individu dengan karakter tersendiri dan organisasi juga memiliki karakter tertentu yang saling menyesuaikan. Latar belakang individu dapat menjadikan ciri-ciri tertentu pada setiap individu. 
Menurut Thoha (dalam Ribhan, 2008:98), individu membawa ke dalam tatanan organisasi, kemampuan, kepercayaan, pribadi, penghargaan, kebutuhan dan pengalamannya. Pendapat lain disampaikan oleh Mathis dan Jackson (2006:113 ) faktor yang mempengaruhi kinerja karyawan yaitu kemampuan karyawan untuk pekerjaan tersebut, tingkat usaha yang dicurahkan, dan dukungan organisasi yang diterimanya. Sehubungan dengan fungsi manajemen manapun, aktivitas manajemen sumber daya manusia harus dikembangkan, dievaluasi, dan diubah apabila perlu, sehingga mereka dapat memberikan kontribusi pada kinerja kompetitif organisasi dan individu di tempat kerja. Faktor-faktor yang mempengaruhi karyawan dalam bekerja, yaitu kemampuan karyawan untuk melakukan pekerjan tersebut, tingkat usaha yang dicurahkan, dan dukungan organisasi. Kinerja karyawan berkurang apabila salah satu faktor ini berkurang atau tidak ada.

Menurut Gomes (2003:142) aspek-aspek kriteria performansi adalah sebagai berikut:

1. Quantity of work, jumlah kerja yang dilakukan dalam suatu periode waktu yang ditentukan.

2. Quality of work, kualitas kerja yang dicapai berdasarkan syarat-syarat kesesuaian dan kesiapan.

3. Job knowledge, luasnya pengetahuan mengenai pekerjaan dan keterampilannya.

4. Creativeness, keaslian gagasan-gagasan yang dimunculkan dan tindakan-tindakan untuk menyelesaikan persoalan-persoalan yang timbul.

5. Cooperation, kesediaan untuk bekerjasama dengan orang lain (sesama anggota organisasi).

6. Dependability, kesadaran dan dapat dipercaya dalam hal kehadiran dan penyelesaian kerja.

7. Initiative, semangat untuk melaksanakan tugas-tugas baru dan dalam tanggung jawabnya.

8. Personal qualities, menyangkut kepribadian, kepemimpinan, keramah-tamahan dan integritas pribadi.

Secara umum kriteria yang digunakan adalah kualitas, kuantitas, waktu yang digunakan, jabatan yang dipegang, absensi dan ketenangan dalam melaksanakan pekerjaan. Kriteria mana yang digunakan adalah berbeda antara pekerjaan yang satu dengan yang lain, jadi pengukuran kinerja tergantung pada jenis pekerjaan dan apa yang dihasilkan oleh organisasi atau institusi yang berkepentingan.

Kerangka konseptual penelitian dapat digambar sebagai berikut:

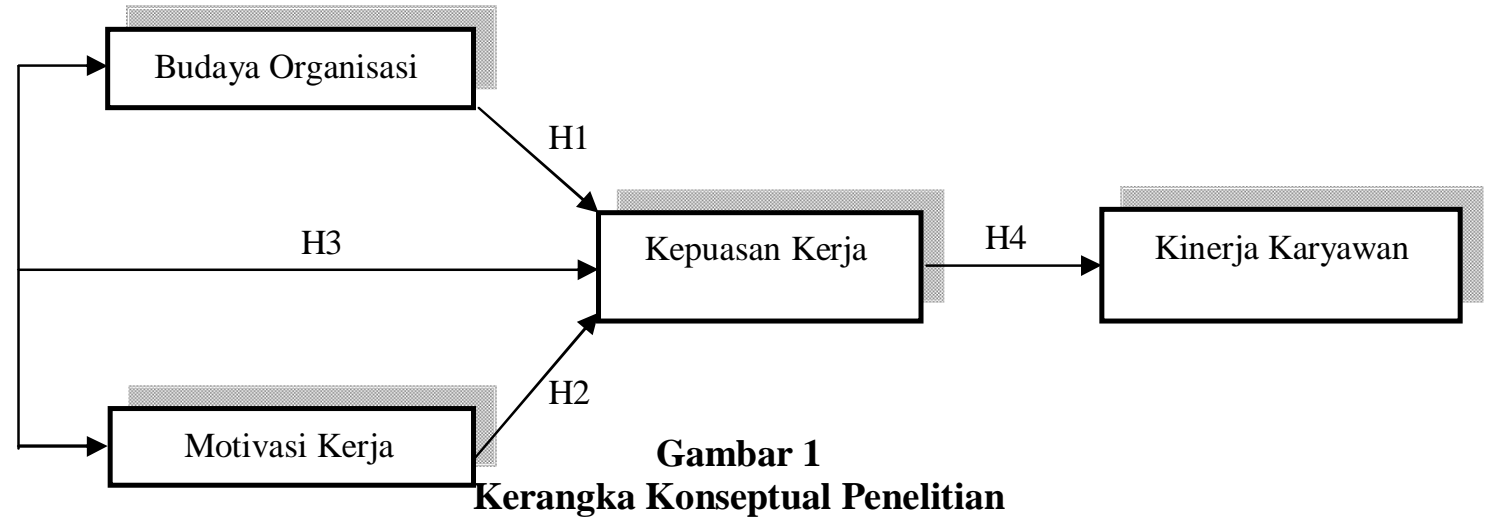

Adapun hipotesis yang diajukan adalah sebagai berikut:

H1: Budaya organisasi mempunyai pengaruh yang signifikan terhadap kepuasan kerja karyawan.

H2: Motivasi kerja mempunyai pengaruh yang signifikan terhadap kepuasan kerja karyawan.

H3: Budaya organisasi dan motivasi kerja mempunyai pengaruh yang signifikan terhadap kepuasan kerja karyawan

H4: Kepuasan kerja mempunyai pengaruh yang signifikan terhadap kinerja karyawan.

Untuk menguji hipotesis-hipotesis tersebut digunakan analisis jalur (path analysis) dan untuk mempermudah pengolahannya menggunakan software PASW Statistic, dengan langkahlangkah sebagai berikut: 
1) Menggambarkan analisis jalur dalam sebuah diagram jalur sehingga terlihat paradigma yang mewakili hiposesis penelitian. Diagram jalur dalam penelitian ini tampak pada gambar berikut :

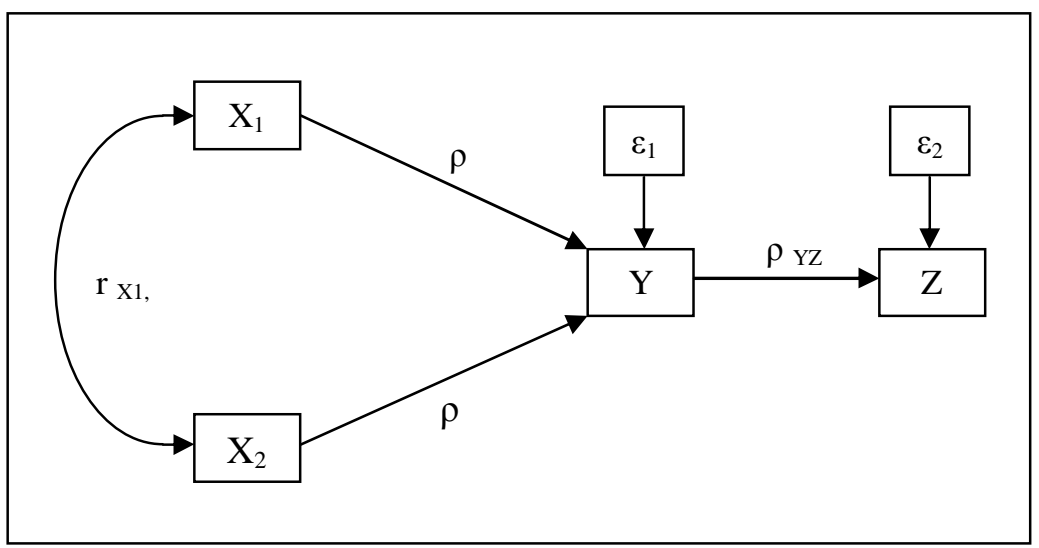

Gambar 2

Analisis Jalur (Path Analysis)

Keterangan :

$\mathrm{X}_{1} \quad=$ Budaya Organisasi

$\mathrm{X}_{2} \quad=$ Motivasi Kerja

$\mathrm{Y} \quad=$ Kepuasan Kerja

$\mathrm{Z} \quad=$ Kinerja Karyawan

$\mathrm{r}_{\mathrm{X} 1 \mathrm{X} 2}=$ Hubungan $\mathrm{X}_{1}$ dengan $\mathrm{X}_{2}$

$\rho_{\mathrm{YX} 1}=$ Pengaruh $\mathrm{X}_{1}$ terhadap $\mathrm{Y}$

$\rho_{\mathrm{YX} 2}=$ Pengaruh $\mathrm{X}_{2}$ terhadap $\mathrm{Y}$

$\rho_{\mathrm{ZY}} \quad=$ Pengaruh $\mathrm{Y}$ terhadap $\mathrm{Z}$

$\varepsilon_{1} \quad=$ Faktor lainnya yang mempengaruhi $\mathrm{Y}$ selain $\mathrm{X}_{1}$ dan $\mathrm{X}_{2}$

$\varepsilon_{2} \quad=$ Faktor lainnya yang mempengaruhi $\mathrm{Z}$ selain $\mathrm{Y}$

Gambar di atas menunjukkan hubungan kausal antara variabel $\mathrm{X}_{1}$ dengan $\mathrm{Y}$, variabel $\mathrm{X}_{2}$ dengan $Y$ serta variabel $Y$ dengan $Z$. Sementara hubungan variabel $X_{1}$ dan $X_{2}$ merupakan hubungan korelasional. Persamaan struktur yang dibentuk adalah :

$$
\mathbf{Y}=\rho_{\mathrm{YX} 1} \mathbf{X} \mathbf{1}+\rho_{\mathrm{YX} 2} \mathbf{X} \mathbf{2}+\varepsilon_{1} \quad \text { dan } \quad \mathbf{Z}=\rho_{\mathrm{ZY}} \mathbf{Y}+\varepsilon_{2}
$$

2) Menghitung dan menyusun matrik koefisien korelasi (r) guna mengetahui korelasi antar variabel.

3) Menghitung koefisien jalur $(\rho)$.

4) Menghitung koefisien determinasi $\left(r^{2}\right)$.

5) Menghitung koefisien jalur epsilon ( $($ ) yang tidak diteliti

6) Melalukan uji signifikansi koefisien jalur secara keseluruhan melalui uji $\mathrm{F}$ dengan kriteria tolak Ho bila $\mathrm{F}_{\text {hitung }}>\mathrm{F}_{\text {table. }}$

7) Melakukan uji signifikansi koefisien jalur secara keseluruhan melalui uji t dengan kriteria tolak Ho bila $t_{\text {hitung }}>t_{\text {table. }}$.

\section{Hasil Penelitian dan Pembahasan}

Responden dalam penelitian ini adalah Karyawan PT Industri Telekomunikasi Indonesia (Persero) yang berjumlah 190 orang. Jumlah tersebut merupakan sampel yang diambil dari 625 orang karyawan.

Hasil uji validitas diketahui bahwa seluruh item dari tiap variabel dinyatakan valid dengan nilai reliabilitasnya 0,931 untuk $\mathrm{X}_{1}, 0,897$ untuk $\mathrm{X}_{2}, 0,896$ untuk $\mathrm{Y}$, dan 0,899 untuk $\mathrm{Z}$. Dengan demikian instrumen penelitian yang digunakan dalam penelitian ini dapat dinyatakan reliabel dan benar-benar sebagai alat ukur yang handal dan memiliki tingkat kestabilan yang tinggi. 
Syarat untuk melakukan analisis jalur adalah adanya hubungan diantara variabel bebas $\left(\mathrm{X}_{1}\right.$ dan $\left.\mathrm{X}_{2}\right)$, dan hubungan antar variabel dapat dilihat dari koefisien korelasinya. Perhitungan analisis korelasi dengan menggunakan korelasi Pearson Product Moment, dilakukan guna mengetahui seberapa kuat hubungan antara beberapa variabel independen yang diteliti pada penelitian ini.

\section{Tabel 1}

Hasil Korelasi antar Variabel Correlations

\begin{tabular}{|ll|r|r|}
\hline & & \multicolumn{1}{|c|}{ X1 } & \multicolumn{1}{|c|}{ X2 } \\
\hline X1 & Pearson Correlation & 1 &, $548^{* *}$ \\
& Sig. (2-tailed) & &, 000 \\
& N & 190 & 190 \\
\hline X2 & Pearson Correlation &, $548^{* * *}$ & 1 \\
& Sig. (2-tailed) &, 000 & 190 \\
N & 190 & \multicolumn{2}{|c|}{} \\
**. Correlation is significant at the 0.01 level (2-tailed).
\end{tabular}

Hubungan antara variabel $\left(\mathrm{X}_{1}\right)$ dengan $\left(\mathrm{X}_{2}\right)$ diperoleh nilai sebesar 0,548. Sehingga apabila dikonsultasikan dengan tabel interpretasi nilai $r$ (korelasi), mempunyai tingkat hubungan yang sedang dan searah karena nilainya positif. Korelasi $\mathrm{X}_{1}$ dan $\mathrm{X}_{2}$ signifikan karena angka signifikansi 0,000 lebih kecil dari pada 0,01. Pernyataan di atas dapat diartikan jika Budaya Organisasi naik satu satuan, maka Motivasi Kerja naik sebesar 0,548.

Sedangkan hubungan antara variabel $\left(\mathrm{X}_{2}\right)$ dengan $\left(\mathrm{X}_{1}\right)$ diperoleh nilai sebesar 0,548. Sehingga apabila dikonsultasikan dengan tabel interpretasi nilai $\mathrm{r}$ (korelasi), mempunyai tingkat hubungan keeratan yang sedang dan searah karena nilainya positif. Korelasi $\mathrm{X}_{2}$ dan $\mathrm{X}_{1}$ signifikan karena angka signifikansi 0,000 lebih kecil dari pada 0,01. Pernyataan di atas dapat diartikan jika $\left(\mathrm{X}_{2}\right)$ naik satu satuan, maka $\left(\mathrm{X}_{1}\right)$ naik sebesar 0,548.

Analisis jalur digunakan untuk menguji besarnya sumbangan (kontribusi) yang ditunjukan oleh koefisien jalur pada setiap diagram jalur dari hubungan kausal antara $X_{1}$ dan $X_{2}$ terhadap Y serta implikasinya terhadap $\mathrm{Z}$ dengan tujuan untuk mengetahui pengaruh langsung maupun tidak langsung sejumlah variabel bebas terhadap variabel terikat. Analisis korelasi dan regresi merupakan dasar dari perhitungan koefisien jalur (Riduan \& Kuncoro, 2008, h.115). Hasil analisis jalur (path analysis) melalui analyze regression linier diuraikan sebagai berikut :

Hasil pengujian secara parsial pengaruh $\left(\mathrm{X}_{1}\right)$ dan $\left(\mathrm{X}_{2}\right)$ terhadap $(\mathrm{Y})$ sebagaimana terlihat pada tabel 2 berikut ini:

Tabel 2

Pengaruh Parsial Variabel $X_{1}$ dan $X_{2}$ terhadap $Y$ Coefficients $^{\mathrm{a}}$

\begin{tabular}{|c|c|c|c|c|c|c|}
\hline \multirow{2}{*}{\multicolumn{2}{|c|}{ Model }} & \multicolumn{2}{|c|}{$\begin{array}{c}\text { Unstandardized } \\
\text { Coefficients }\end{array}$} & \multirow{2}{*}{$\begin{array}{c}\text { Standardized } \\
\text { Coefficients } \\
\text { Beta }\end{array}$} & \multirow[b]{2}{*}{ t } & \multirow[b]{2}{*}{ Sig. } \\
\hline & & B & Std. Error & & & \\
\hline \multirow[t]{3}{*}{1} & (Constant) & 10,702 & 2,029 & & 5,273 & ,000 \\
\hline & $\mathrm{X} 1$ & ,430 & , 038 & , 480 & 11,325 & , 000 \\
\hline & $\mathrm{X} 2$ & ,524 & ,043 & ,513 & 12,100 & ,000 \\
\hline
\end{tabular}

a. Dependent Variable: $Y$

Kemudian Pengaruh simultan dari variabel bebas terhadap variabel terikat diketahui nilai koefisien regresi berganda dan koefisien determinasi. Koefisien determinasi (square multiple correlation) merupakan koefisien yang digunakan untuk mengetahui besarnya kontribusi variabel independen terhadap perubahan variabel dependen. Hasil analisis jalur dari 
pengaruh simultan variabel $\left(\mathrm{X}_{1}\right)$ dan $\left(\mathrm{X}_{2}\right)$ terhadap $(\mathrm{Y})$ sebagaimana terlihat pada tabel 3 berikut ini:

Tabel 3

Pengaruh simultan variabel bebas terhadap variabel terikat

Model Summary

\begin{tabular}{|l|l|r|r|r|}
\hline Model & $\mathrm{R}$ & R Square & $\begin{array}{c}\text { Adjusted R } \\
\text { Squre }\end{array}$ & $\begin{array}{c}\text { Std. Error of } \\
\text { the Estimate }\end{array}$ \\
\hline 1 &, $874^{\mathrm{a}}$ &, 764 &, 762 & 4,28931 \\
\hline
\end{tabular}

a. Predictors: (Constant), X2, X1

Sedangkan hasil pengujian secara parsial pengaruh Kepuasan Kerja (Y) terhadap Kinerja Karyawan $(Z)$ sebagaimana terlihat pada tabel 4 berikut ini:

Tabel 4

Pengaruh Parsial Variabel Kepuasan Kerja (Y) terhadap Kinerja Karyawan (Z)

Coefficients $^{\mathbf{a}}$

\begin{tabular}{|c|c|c|c|c|c|}
\hline \multirow[t]{2}{*}{ Model } & \multicolumn{2}{|c|}{$\begin{array}{l}\text { Unstandardized } \\
\text { Coefficients }\end{array}$} & $\begin{array}{l}\text { Standardized } \\
\text { Coefficients }\end{array}$ & & \\
\hline & B & Std. Error & Beta & $\mathrm{t}$ & Sig. \\
\hline $\begin{array}{ll}1 & \text { (Constant) } \\
& \text { Y }\end{array}$ & $\begin{array}{r}1,033 \\
, 924\end{array}$ & $\begin{array}{r}1,974 \\
, 033\end{array}$ & 900 & $\begin{array}{r}, 523 \\
28,384 \\
\end{array}$ & $\begin{array}{l}, 601 \\
, 000\end{array}$ \\
\hline
\end{tabular}

a. Dependent Variable: $\mathrm{Z}$

Dengan demikian dapat diketahui hasil penghitungan analisis jalur (Path analysis) sebagaimana terlihat pada gambar 3 berikut ini:

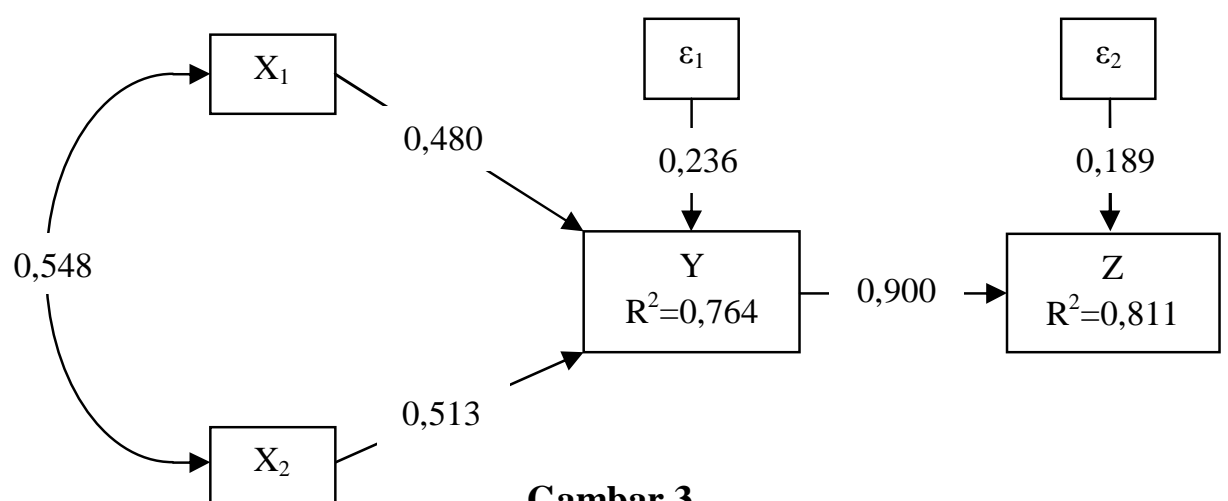

Gambar 3

Hasil Analisis Jalur berikut ini :

Berdasarkan gambar 3 di atas, dapat diformulasikan hasil pengujian melalui tabel 5

Tabel 5

Hasil Perhitungan Jalur

\begin{tabular}{|l|c|}
\hline \multicolumn{1}{|c|}{ Variabel } & Koefisien Jalur \\
\hline Budaya Organisasi $\left(\mathrm{X}_{1}\right)$ & 0,480 \\
\hline Motivasi Kerja $\left(\mathrm{X}_{2}\right)$ & 0,513 \\
\hline Kepuasan Kerja $(\mathrm{Y})$ & 0,900 \\
\hline
\end{tabular}

Sumber : Hasil perhitungan statistik

Tabel 5 di atas menggambarkan hasil perhitungan jalur yaitu bahwa variabel $\mathrm{X}_{1}$ mempunyai koefisien jalur 0,480 , Variabel $\mathrm{X}_{2}$ koefisien jalurnya 0,513 , dan Variabel $\mathrm{Y}$ 
koefisien jalurnya 0,900. Dari hasil analisis jalur tersebut dapat dibentuk persamaan jalur sebagai berikut:

$\mathrm{Y}=0,480 \mathrm{X}_{1}+0,513 \mathrm{X}_{2}+\varepsilon_{1}$

$\mathrm{Z}=0,900 \mathrm{Y}+\varepsilon_{2}$

Keterangan :

$\mathrm{Z}$ = Kinerja Karyawan

$\mathrm{Y} \quad=$ Kepuasan Kerja

$\mathrm{X}_{1} \quad$ = Budaya Organisasi

$\mathrm{X}_{2} \quad=$ Motivasi Kerja

Sesuai dengan hasil penghitungan analisis jalur, maka berikut ini disajikan pengaruh total, pengaruh langsung, dan pengaruh tidak langsung setiap variabel sebagaimana terlihat pada tabel 6 berikut ini:

Tabel 6

Pengaruh Todal, Pengaruh Langsung dan Tidak Langsung

\begin{tabular}{|c|c|c|c|c|c|}
\hline \multirow{3}{*}{ Variabel } & \multicolumn{4}{|c|}{ Kepuasan Kerja (Y) } & \multirow{3}{*}{$\begin{array}{c}\text { Kinerja } \\
\text { Karyawan } \\
(\mathrm{Z})\end{array}$} \\
\hline & \multirow[b]{2}{*}{ Langsung } & \multicolumn{2}{|c|}{ Tidak Langsung } & \multirow[b]{2}{*}{ TOTAL } & \\
\hline & & $\mathbf{X}_{1}$ & $\mathbf{X}_{2}$ & & \\
\hline Budaya Organisasi $\left(\mathrm{X}_{1}\right)$ & $23.0 \%$ & - & $13.5 \%$ & $36.5 \%$ & - \\
\hline Motivasi Kerja $\left(\mathrm{X}_{2}\right)$ & $26.3 \%$ & $13.5 \%$ & - & $39.8 \%$ & - \\
\hline Kepuasan Kerja (Y) & - & - & - & - & $81.1 \%$ \\
\hline Total & $49.3 \%$ & $13.5 \%$ & $13.5 \%$ & $76.3 \%$ & \\
\hline
\end{tabular}

Berdasarkan tabel 6 di atas, terlihat bahwa variabel $\left(\mathrm{X}_{1}\right)$ mempunyai pengaruh langsung sebesar $23,0 \%$, pengaruh tidak langsung melalui hubungannya dengan $\left(\mathrm{X}_{2}\right)$ sebesar $13,5 \%$, sehingga total pengaruhnya adalah sebesar $36,5 \%$.

Variabel $\left(\mathrm{X}_{2}\right)$ mempunyai pengaruh langsung sebesar $26,3 \%$, pengaruh tidak langsung melalui hubungannya dengan $\left(X_{1}\right)$ sebesar $13,5 \%$, sehingga total pengaruhnya sebesar $39,8 \%$. Total pengaruh secara keseluruhan $\left(\mathrm{X}_{1}\right)$, dan $\left(\mathrm{X}_{2}\right)$ terhadap $(\mathrm{Y})$ adalah sebesar $76,3 \%$.

Sedangkan faktor lain yang tidak diteliti dan turut mempengaruhi (Y) ditunjukan oleh nilai $\mathrm{P}_{\mathrm{y}} \varepsilon=0,237$ atau sebesar $23,7 \%$.

Kontribusi variabel (Y) terhadap (Z) adalah sebesar 81,1\% atau R Square 0,811, sedangkan sisanya $18,9 \%$ merupakan variabel lain yang tidak diteliti dalam penelitian ini.

\section{Uji Hipotesis Secara Simultan}

Pengujian hasil penelitian secara keseluruhan antara $\left(\mathrm{X}_{1}\right)$ dan $\left(\mathrm{X}_{2}\right)$ terhadap $(\mathrm{Y})$ serta implikasinya terhadap $(\mathrm{Z})$ menggunakan hipotesis statistik sebagai berikut :

a. Hipotesis secara simultan

$\mathrm{H}_{0}: \rho_{\mathrm{YX} 1}=\rho_{\mathrm{YX} 2}=0 \quad: \quad\left(\mathrm{X}_{1}\right)$ dan $\left(\mathrm{X}_{2}\right)$ tidak berpengaruh terhadap $(\mathrm{Y})$.

$\mathrm{H}_{1}: \rho_{\mathrm{YX} 1} \neq \rho_{\mathrm{YX} 2} \neq 0 \quad: \quad\left(\mathrm{X}_{1}\right)$ dan $\left(\mathrm{X}_{2}\right)$ berpengaruh terhadap $(\mathrm{Y})$.

Dengan kriteria uji : tolak $\mathrm{H}_{0}$ jika $\mathbf{F}_{\text {hitung }}>\mathbf{F}_{\text {tabel }}$

Dari hasil perhitungan Software PASW Statistics 18, dari uji Anova diperoleh bahwa $F_{\text {hitung }}$ adalah 302,880. Derajat kebebasan (DK) dengan ketentuan numerator: jumlah variabel 1 atau $4-1=3$; dan denumerator: jumlah kasus $-\mathrm{n}$ atau $190-4=186$. Dengan ketentuan tersebut dan tingkat signifikan $\alpha=5 \%$, maka diperoleh angka $F_{\text {tabel }}$ sebesar 2,65. Oleh karena $\mathrm{F}_{\text {hitung }}>\mathrm{F}_{\text {tabel }}(302,880>2,65)$ atau nilai signifikansi (probabilitas) $0,000^{\mathrm{a}}$ jauh lebih kecil dari $0,05(\alpha)$, maka $\mathrm{H}_{0}$ ditolak. Sehingga dapat disimpulkan bahwa terdapat pengaruh yang signifikan antara variabel $\left(\mathrm{X}_{1}\right)$ dan $\left(\mathrm{X}_{2}\right)$ terhadap $(\mathrm{Y})$. 


\section{Uji Hipotesis Secara Parsial}

Pengaruh Budaya Organisasi $\left(\mathbf{X}_{1}\right)$ terhadap Kepuasan Kerja (Y)

Untuk mengetahui signifikansi pengaruh secara parsial variabel $\left(\mathrm{X}_{1}\right)$ terhadap $(\mathrm{Y})$, perlu dilakukan pengujian statistik. Maka untuk mengujinya akan menggunakan hipotesis statistik sebagai berikut :

- Pengaruh $\mathrm{X}_{1}$ terhadap $\mathrm{Y}$

$$
\begin{array}{lll}
\mathrm{H}_{0}: \rho_{\mathrm{YX} 1}=0 & : & \left(\mathrm{X}_{1}\right) \text { tidak berpengaruh terhadap }(\mathrm{Y}) . \\
\mathrm{H}_{1}: \rho_{\mathrm{YX} 1} \neq 0 & : \quad\left(\mathrm{X}_{1}\right) \text { berpengaruh terhadap }(\mathrm{Y}) .
\end{array}
$$

Dengan kriteria uji : tolak $\mathrm{H}_{0}$ jika $\mathbf{t}_{\text {hitung }}>\mathbf{t}_{\text {tabel }}$

Tabel 7

Signifikansi Budaya Organisasi $\left(\mathrm{X}_{1}\right)$ terhadap Kepuasan Kerja (Y)

\begin{tabular}{|c|c|c|c|c|c|}
\hline Struktural & $\begin{array}{c}\text { Koefisien } \\
\text { jalur }\end{array}$ & $\mathbf{t}_{\text {hitung }}$ & $\mathbf{t}_{\text {tabel }}$ & Sig & Kesimpulan \\
\hline$\rho_{\mathrm{yx} 1}$ & 0,480 & 11,325 & 1,653 & 0,000 & $\mathrm{H}_{0}$ ditolak \\
\hline
\end{tabular}

Untuk menguji hipotesis tersebut, diperlukan nilai koefisien jalur. Hasil perhitungan menunjukkan nilai $\mathbf{t}_{\text {hitung }}$ adalah 11,325 . Dengan tingkat signifikansi $(\alpha)=5 \%$ derajat kebebasan (degree of freedom $)=\mathrm{n}-\mathrm{k}$ atau $1904=186$ dan pengujian dilakukan uji satu arah, maka di peroleh $\mathbf{t}_{\text {tabel }}$ sebesar 1,653. Oleh karena $\mathbf{t}_{\text {hitung }}>\mathbf{t}_{\text {tabel }}(11,325>1,653)$ dan nilai signifikansi $=$ 0,000 lebih kecil dari 0,05 $(\alpha)$, maka $\mathbf{H}_{\mathbf{0}}$ ditolak. Sehingga dapat disimpulkan bahwa Budaya Organisasi $\left(\mathrm{X}_{1}\right)$ berpengaruh signifikan terhadap Kepuasan Kerja $(\mathrm{Y})$.

\section{Pengaruh Motivasi Kerja $\left(\mathbf{X}_{2}\right)$ terhadap Kepuasan Kerja (Y)}

Untuk mengetahui signifikansi pengaruh secara parsial variabel $\left(\mathrm{X}_{2}\right)$ terhadap $(\mathrm{Y})$, perlu dilakukan pengujian statistik. Maka untuk mengujinya akan menggunakan hipotesis statistik sebagai berikut :

- Pengaruh $\mathrm{X}_{2}$ terhadap $\mathrm{Y}$

$$
\begin{array}{lll}
\mathrm{H}_{0}: \rho_{\mathrm{YX} 2}=0 & : & \left(\mathrm{X}_{2}\right) \text { tidak berpengaruh terhadap }(\mathrm{Y}) . \\
\mathrm{H}_{1}: \rho_{\mathrm{YX} 2} \neq 0 & : & \left(\mathrm{X}_{2}\right) \text { berpengaruh terhadap }(\mathrm{Y}) .
\end{array}
$$

Dengan kriteria uji : tolak $\mathrm{H}_{0}$ jika $\mathbf{t}$ hitung $>\mathbf{t}$ tabel

Tabel 8

Signifikansi Motivasi Kerja $\left(\mathrm{X}_{2}\right)$ terhadap Kepuasan Kerja (Y)

\begin{tabular}{|c|c|c|c|c|c|}
\hline Struktural & $\begin{array}{c}\text { Koefisien } \\
\text { Jalur }\end{array}$ & $\mathbf{T}_{\text {hitung }}$ & $\mathbf{T}_{\text {tabel }}$ & Sig & Kesimpulan \\
\hline$\rho_{\mathrm{yx} 2}$ & 0,513 & 12,100 & 1,653 & 0,000 & $\mathrm{H}_{0}$ ditolak \\
\hline
\end{tabular}

Untuk menguji hipotesis tersebut, diperlukan nilai koefisien jalur. Hasil perhitungan menunjukkan nilai $\mathbf{t}_{\text {hitung }}$ adalah 12,100 . Dengan tingkat signifikansi $(\alpha)=5 \%$ derajat kebebasan (degree of freedom $)=\mathrm{n}-\mathrm{k}$ atau $190-4=186$ dan pengujian dilakukan uji satu arah, maka di peroleh $\mathbf{t}_{\text {tabel }}$ sebesar 1,653. Oleh karena $\mathbf{t}_{\text {hitung }}>\mathbf{t}_{\text {tabel }}(12,100>1,653)$ dan nilai signifikansi $=$ 0,000 lebih kecil dari 0,05 $(\alpha)$, maka $\mathbf{H}_{\mathbf{0}}$ ditolak. Sehingga dapat disimpulkan bahwa Motivasi Kerja $\left(\mathrm{X}_{2}\right)$ berpengaruh signifikan terhadap Kepuasan Kerja (Y).

\section{Pengaruh Kepuasan Kerja (Y) terhadap Kinerja Karyawan (Z)}

Untuk mengetahui signifikansi pengaruh secara parsial variabel (Y) terhadap (Z), perlu dilakukan pengujian statistik. Maka untuk mengujinya akan menggunakan hipotesis statistik sebagai berikut :

- Pengaruh Y terhadap Z

$$
\begin{array}{lll}
\mathrm{H}_{0}: \rho_{\mathrm{YZ}}=0 & : & (\mathrm{Y}) \text { tidak berpengaruh terhadap (Z). } \\
\mathrm{H}_{1}: \rho_{\mathrm{YZ}} \neq 0 & : \quad \text { (Y) berpengaruh terhadap (Z). }
\end{array}
$$

Dengan kriteria uji : tolak $\mathrm{H}_{0}$ jika $\mathbf{t}$ hitung $>\mathbf{t}$ tabel 
Tabel 9

Signifikansi Kepuasan Kerja (Y) terhadap Kinerja Karyawan (Z)

\begin{tabular}{|c|c|c|c|c|c|}
\hline Struktural & $\begin{array}{c}\text { Koefisien } \\
\text { Jalur }\end{array}$ & $\mathbf{t}_{\text {hitung }}$ & $\mathbf{t}_{\text {tabel }}$ & Sig & Kesimpulan \\
\hline$\rho_{\mathrm{y} \times 2}$ & 0,900 & 28,384 & 1,653 & 0,000 & $\mathrm{H}_{0}$ ditolak \\
\hline
\end{tabular}

Untuk menguji hipotesis tersebut, diperlukan nilai koefisien jalur. Hasil perhitungan menunjukkan nilai $\mathbf{t}_{\text {hitung }}$ adalah 28,384. Dengan tingkat signifikansi $(\alpha)=5 \%$ derajat kebebasan (degree of freedom $)=\mathrm{n}-\mathrm{k}$ atau $190-4=186$ dan pengujian dilakukan uji satu arah, maka di peroleh $\mathbf{t}_{\text {tabel }}$ sebesar 1,653 . Oleh karena $\mathbf{t}_{\text {hitung }}>\mathbf{t}_{\text {tabel }}(28,384>1,653)$ dan nilai signifikansi $=$ 0,000 lebih kecil dari 0,05 $(\alpha)$, maka $\mathbf{H}_{\mathbf{0}}$ ditolak. Sehingga dapat disimpulkan bahwa Kepuasan Kerja (Y) berpengaruh signifikan terhadap Kinerja Karyawan (Z).

\section{Kesimpulan}

Berdasarkan hasil analisis data dengan menggunakan path analysis dan pembahasan hasil penelitian yang telah dikemukakan sebelumnya, maka dapat disimpulkan sebagai berikut:

1) Budaya organisasi berpengaruh terhadap kepuasan kerja dengan besarnya pengaruh langsung sebesar 0,230 atau $23,0 \%$, sedangkan pengaruh tidak langsung melalui motivasi kerja adalah sebesar 0,135 atau $13,5 \%$, sehingga total pengaruh Budaya Organisasi terhadap kepuasan kerja adalah sebesar 0,365 atau 36,5\%, berada pada kategori Lemah.

2) Motivasi kerja berpengaruh terhadap kepuasan kerja dengan besarnya pengaruh langsung sebesar 0,263 atau $26,3 \%$, sedangkan pengaruh tidak langsung melalui budaya organisasi adalah sebesar 0,135 atau $13,5 \%$, sehingga total pengaruh motivasi kerja terhadap kepuasan kerja adalah sebesar 0,398 atau 39,8\%, berada pada kategori Lemah.

3) Budaya organisasi dan motivasi kerja secara simultan berpengaruh terhadap kepuasan kerja karyawan sebesar 0,764 atau 76,4\%, berada pada kategori Kuat, sedangkan sisanya sebesar 0,236 atau $23,6 \%$ merupakan kontribusi variabel lain yang tidak diteliti dalam penelitian ini.

4) Kepuasan kerja berpengaruh terhadap kinerja karyawan sebesar 0,811 atau $81,1 \%$, berada pada kategori Sangat Kuat, sedangkan sisanya sebesar 0,189 atau 18,9\% merupakan kontribusi variabel lain yang tidak diteliti dalam penelitian ini.

\section{Daftar Pustaka}

Dwi Ermayanti, dan Armanu Thoyib, (2001). Pengaruh Faktor Motivasi Terhadap Prestasi Kerja Karyawan pada Kantor Perum Perhutani Unit II Surabaya, Jurnal Fakultas Ekonomi Universitas Brawijaya Malang.

Faustino Cardoso Gomes. (2003). Manajemen Sumber Daya Manusia. Yogyakarta: Penerbit Andi.

H.Teman Koesmono. (2005). Pengaruh Budaya Organisasi, Terhadap Motivasi dan Kepuasan Kerja Serta Kinerja Karyawan Pada Sub Sektor Industri Pengolahan Kayu Skala Menengah Di Jawa Timur. Jurnal Manajemen \& Kewirausahaan, Vol. 7 No. 2.

Hendro Adiarso dan Eko Napitupulu. (2010). Terobosan Berani dari Industri Telekomunikasi Dari Situasi Carut Marut ke Peningkatan Laba. Forum Manajemen Prasetiya Mulya, Vol XXIV No. 04, Juli - September 2010.

Ida Ayu Brahmasari dan Agus Suprayetno. (2008). Pengaruh Motivasi Kerja, Kepemimpinan, dan Budaya Organisasi Terhadap Kepuasan Kerja Karyawan Serta Dampaknya Pada Kinerja Perusahaan (Studi Kasus pada PT Peri Hai International Wiratama Indonesia). 
Jurnal Manajemen \& Kewirausahaan, Vil. 10, No. 2, September 2008. Petra Christian University. Surabaya.

Keputusan Menteri Badan Usaha Milik Negara Nomor : KEP-117/M-MBU/2002 Tentang Penerapan Praktek Good Corporate Governance Pada Badan Usaha Milik Negara (BUMN).

Luthans, Fred. (2006). Perilaku Organisasi. Edisi Indonesia. Yogyakarta: Penerbit ANDI.

Makmuri Muchlas. (2005). Perilaku Organisasi. Yogyakarta: Gadjah Mada University Press.

Mathis, Robert L. dan Jackson, John H. (2006). Manajemen Sumber Daya Manusia. Jakarta: Salemba Empat.

Moeheriono. (2009). Pengukuran Kinerja Berbasis Kompetensi. Cetakan Pertama. Bogor: Penerbit Ghalia Indonesia.

Praningrum. (2002). Pengaruh Praktek Manajemen Sumber Daya Manusia Terhadap Komitmen Pimpinan Pada Kualitas di Rumah Sakit Kota Bengkulu. JURNAL EKONOMI \& BISNIS No. 3 Jilid 7, Tahun 2002. Fakultas Ekonomi Universitas Bengkulu. Bengkulu.

Ribhan. (2008). Hubungan Karakteristik Individu Dengan Kinerja Karyawan Melalui Komitmen Organisasi Sebagai Variabel Mediasi (Studi Kasus pada PT Chandra Superstore Tanjung Karang Bandar Lampung), Jurnal Bisnis dan Manajemen, Volume 4 No.2, Januari 2008.

Riduan dan Engkos Achman Kuncoro. (2008). Cara Menggunakan dan Memakai Analisis Jalur (Path Analysis). Bandung: Alfabeta.

Robbins, Stephen P., dan Timothy A. Judge. (2008). Perilaku Organisasi. Jakarta: Penerbit Salemba Empat.

Sudarwan Danim. (2004). Motivasi Kepemimpinan \& Efektivitas Kelompok. Cetakan Pertama. Jakarta: Penerbit PT. Rineka Cipta.

Undang-undang Nomor 19 Tahun 2003 Tentang Badan Usaha Milik Negara.

Veithzal Rivai, Ahmad Fawzi, Ella Jauvani Sagala, Silviana Murni. (2008). Performance Appraisal Sistem Yang Tepat Untuk Menilai Kinerja Karyawan dan Meningkatkan Daya Saing Perusahaan. Edisi Kedua. Jakarta: Penerbit PT. Raja Grafindo Persada.

Veithzal Rivai, Ella Jauvani Sagala. (2010). Manajemen Sumber Daya Manusia untuk Perusahaan Dari Teori ke Praktek. Edisi Kedua. Jakarta: Penerbit PT. RajaGrafindo Persada.

Wibowo. (2010). Budaya Organisasi Sebuah Kebutuhan Untuk Meningkatkan Kinerja Jangka Panjang. Jakarta: PT RajaGrafindo Persada.

Wibowo. (2011). Manajemen Kinerja. Jakarta: PT Raja Grafindo Persada.

http://www.inti.co.id

http://www.bumn.go.id 